\title{
Management of Multi-campus Universities in American and its enlightenment on Chinese Multi-campus Universities
}

\author{
Yaohua $\mathrm{Wu}^{1}$, Zhihui $\mathrm{Wu}^{2}$ \\ 1. School of Business Administration \\ 2. Guangzhou Institute of Modern Industrial Technology \\ South China University of Technology \\ Guangzhou, P. R. China \\ e-mail: yhwu@scut.edu.cn
}

\begin{abstract}
-for improving management performance, the comparison of conception about multi-campus university between the US and China is compared firstly. Secondly, the formation background of their multi-campus university is analyzed. To enlighten the successful experience from the US universities management, the characteristics including management mode, education quality system, financing channels, interactions between teachers and students, and cultural combination are discussed in detail. Finally, four points are draw out for Chinese universities improving campuses management, which consists of management model, educational quality, running model and characteristics developing road.
\end{abstract}

Keywords-multi-campus universities; university management; enlightenment; America

\section{INTRODUCTION}

In 1960, the United States was born out of the first multicampus university system, the California higher education system, which meant the multi-campus universities in the United States developing rapidly. Since the mid 1980, there have been multi-campus phenomenon in Chinese universities own expansion and the process of merger. How to manage effectively in multi-campus university, are both a practical aspect of management in the university, and a theoretical problem of management studies about the university, which come to be the hot spots gradually. In studying the problems need to pay attention to absorb useful experience of other countries, but also important to avoid indiscriminate copying the results of others.

In this paper, the experience and the mode of multicampus universities in United States are investigated through the following areas, including the comparison of conception about multi-campus university, and the background, the analysis on the characteristics in the U.S. Finally, the inspiration of multi-campus university management is concluded to activate our idea and broaden our horizons.

\section{THE COMPARISON OF THE CONCEPT OF MULTI- CAMPUS UNIVERSITIES BETWEEN THE U.S. AND CHINA}

There is a different understanding of the concept of multi-campus universities between in the U.S. and in China. In the United States, the multi-campus university means two or more of four-year campuses higher education system, which is only controlled by a single legal management of the management committee. The management committee or the executive branch of the multi-campus university system has a clear division of responsibility from the various branch schools [1-3]. Meanwhile, multi-campus university represents the university having an independent legal personality, at least more than two campuses, which each campus location is not connected in China, such as Zijingang campus of Zhejiang University, Minxing campus of East China Normal University, and so on. Campuses are different from branch schools. Generally, the branch schools have the relative independent autonomy, including the right to personnel, finance, but the campuses do not have [4-5].

For the United States university system, each branch school is a relative independent running entity, having own reputation in the community, having the separated statistics in colleges and universities classification statistics. But the government only appropriate unified funding to a university system. And the university principal office and subsidiary sector are responsible for the total budget and public relations such as public affairs, the coordination university system fundamental policy, while the branch schools form their respective running characteristics.

The American university system acts as a policy coordinator, public service providers, and agent between the government and the various branch schools. The university system would be the buffer of improper interference by the government and the excessive autonomy of campus. In external relations, the university system is a chorus consisting of more than one sound. Therefore, the most correct form of address for the multi-campus university in the United States is multi-branch school system. It should be called the branch school rather than campus.

In China, the management mode and system of the multicampus university are not the same, but each campus of university has only a unified legal person. Their independence is relatively weak, since they have to receive unified leadership and guidance from headquarters, also to do "Five Unified", unified the school principals, unified institutions and leadership, unified management system, unified development planning, and unified subject construction. 


\section{CONTRAST BETWEEN THE U.S. AND CHINA IN BACKGROUND OF MULTI-CAMPUS UNIVERSITIES}

\section{A. Background of the formation of Multi-campus Universities in U.S.}

Formation of multi-campus university in the U.S. is a process of natural development of higher education with its expansion. The management of multi-campus university in the United States is a typical management model, which has become a mainstream form of American public higher education. The system is formed with the development of the state or public university and gradually built up. In 1862, the Morrill Act was enacted in U.S., which did a significant contribution to the local enthusiasm for founding institutions of higher learning, enabling States to gradually establish their own state university, laid the foundation for development of American public university. However, the big development came after the Second World War. Due to the promulgation and implementation of the Military Act, the United States and the Soviet Union, the two camps against the arms race, especially space race. Since international competition increased, the US government increase the investment in higher education and science and technology substantially, which greatly prompted the rapid development of higher education, in particular the great development of public higher education. There are only $10 \%$ of Americans to go to college before World War II, and the figure jumped to $51 \%$ after World War II. In order to meet the urgent need of rapid expansion for citizens eager to go to college, states develop public higher education. However, as independent state universities were established constantly, rapid increase in the number, the state education department made the original direct management of the universities was the most troublesome problem. To solve the problem, the state government established a system for the new public universities in order to facilitate administration, improve the efficiency and effectiveness of management in higher education. The Office of the system coordinates the relationship between state universities, and the relationship between the state governments.

\section{B. Background of the formation of Multi-campus Universities in China}

In China, the formation of multi-campus university has its specific background, it's not all universities in the development process for its own internal needs natural extension, but in the macro-management in the context of the reform of higher education, mainly rely on administrative power-driven results. Specific performance is as following.

1) The Policy Guidance: Before the merging of universities, the government proposed formation of reform as cooperative education, transfer, merger and collaboration of running. The government guides the merger of universities and colleges in entire process. In addition, the college enrollment is from the document and the guidelines issued by the Ministry of Education, which lead to the university new campus expansion.
2) Promoting the Merger: In merge process, the government took chief efforts to contribute university merge, such as, three universities belongs to the original machinery the Department, Harbin Science and Technology University, Harbin Electric Institute of Technology, and Harbin Industrial High College, are merged in 1995 with efforts of the machinery department. The government also used economic means boot the university merge, for example, during the Tongji University reform, Shanghai City dial to 15 million of start funding, the state development planning commission implemented 88 million of special funding, Shanghai City then supported 10 million as matching funding, Tongji University received the number of start funding.

3) To Address the Problem: Since there have been many contradictions and conflicts involving the combination of universities, it should be resolved to consolidate institutions rely on their own. But for the reform point, the government took part in the combination of universities. In short, in the course of the merger, the government almost acted in whole progress.

\section{The Characteristics OF Multi-CAMPUS UNIVERSITY IN THE US}

\section{A. Characteristics of the Management Mode}

Multi-campus university system is a typical management model and the mainstream form of public higher education in the United States. Management model of multi-campus university in the US have four characteristics.

- Board of Directors is set in the university system. The principal of the university system is adopted by the board of directors with some procedures of selecting, appointing. President or chairman of the board is responsible of the management or organization for various independent universities in the university system.

- The board of directors focuses on the entire system, whose main responsibility is to develop the overall development planning and extensive policy for each campus, and to ensure the effective implementation of plans and policies, but not to a specific intervention in the university affairs.

- Each university in the system has a strong sense of independence. Its administration, finance, academic research, and so on will not be subject to any control of the university system, the principal of the university system comes with the recommendations produced by the university itself, while the appointment and oversight are controlled by the board of directors.

- In order to improve efficiency and reduce duplication, the university system provides common interest services that the universities cannot independently accomplish, such as legal advice, procurement. The system only makes necessary 
supervision of the university academic, research direction and quality, and actively encourages cooperation between universities in the university system.

\section{B. Education Quality System}

In the United States, the improvement of the education quality is concerned by the government. The Malcom Baldrige National Quality Award is the highest quality and performance national awards, which aim is to promote the competitiveness of American businesses, improve management and organizational performance, identify achievements and quality performance of the organization, and show its successful performance strategies to the public, that all other organizations could share its success. From 1999, the Malcom Baldrige National Quality Award has opened to educational organizations to provide education services. Any for-profit or non-profit public and private organizations of education services in the United States are eligible to apply for the award. Besides the Baldrige awards, the university has also developed a series of measures to improve the quality of education as following.

- To strengthen the research-oriented university teaching function. Teachers are pursuit of a tenured professor, spending all time and energy on scientific research projects rather than teaching. And teaching quality provided by graduate students to undergraduate is not high, eventually leading to decline in the quality of graduates. On the other hand, full-time university teacher, graduate teaching assistants and mentoring for new teachers must be trained and developed.

- Using inquiry learning methods. Inquiry learning is a form of undergraduate education through the whole process of learning. It is made up of three parts step by step. Firstly, it is junior seminar and tutorial course, that make the students understand the meaning of scientific research. Secondly, high-grade students take part in research projects. Thirdly, it is the peak experience before graduation, including dissertation, graduate design, advanced workshops, research projects, performance, practice, or field work, preparing for further graduate education of the students.

- To focus on the integration of interdisciplinary curriculum and courses. In order to reverse the tendency to emphasis on scientific and despise the humanities. The universities have removed interdisciplinary education barriers, created multidisciplinary mechanism for undergraduate education, and guided students in interdisciplinary studies.

- To take informal education as an important component of undergraduate education. The university should take full advantage of a variety of conditions and activities on campus. And all kinds of debates, concerts, sporting events become part of the educational experience of students. The university also offer specialized classroom discussions and similar course. The transfer students from community colleges will develop into the practice of university research.

\section{Financing Channels}

The multi-campus university system in the United States is a huge system. The school funding, research funding every year are the heavy cost. The universities use flexible mechanisms and variety of sources to raise funds in the following way.

- In recent years, government funding is still the main position for about 55 percent in the sources of funding for public universities. For the research fee, the US government funding of more than 10 billion USD every year, accounting for 60 percent of research funding in the national universities.

- Recruiting foreign students also become an important measure to ease the shortage of school funding in the United States. According to statistics, during the past 20 years, the number of foreign students in American colleges and universities has increased by three times. The number of students increased sharply brought considerable economic income for American colleges and universities.

- Bond is also one of the main ways to raise money in American universities, such as Yale University issued trans-century bonds in the 1996 for 100 years. Issued bonds can be raise funds for school construction of large projects. For universities, in particular a certain reputation of famous universities, the Americans not only feel a sense of identity, but also clearly know what the money are used for.

- Patent funding of scientific research also become a common phenomenon in some university with good research facilities and strong technical force. Such as the University of Arizona gain from franchise of the high-yielding hybrid cotton.

- Institutionalized and standardized donations became the major source of funding for the development of the university. Meanwhile, donations is encouraged and supported by the government. On one hand, government provides the appropriate tax breaks for donors for giving donors a double return on the economy and reputation. On the other hand, special policies are developed to encourage donations.

\section{Ideology of Interactions between Teachers and Students}

The important characteristic of teacher and student communication in America is mutual respecting and loving [6]. In the United States campuses, the teacher is not seen as a perfect god, but a limited one. The students can exchange views with them on an equal position, and even argue issues. The concept of honoring the teacher and respecting his teaching in America is the same traditional deep as the oriental culture. But the relationship between teachers and students focus on creating a more relaxed climate of equality. In fact, as an interactive process of human to human, the relationship between teacher and student educators in the 
United States fully embodies their unique personality, mutual understanding and respecting.

\section{E. Feature of Cultural Combination}

American campus of the multi-campus university system is relatively independent. Each branch can have very different characteristics of running characteristics, culture. Therefore, cultural integration problem of multi-campus university does not exist because of the campus of increasing in the U.S. The United States is a developed immigrant country. Its national culture is complex with not deep history culture foundation. Various cultures in this land make penetration, effects, collision and fusion each other, which lead to the formation of powerful vitality immigrants culture hybrid advantage, in particularly at the industrial revolution and science and technology progress. Those strongly promote development and the formation of the United States university organization management thought with some tolerance characteristics and multi-culture features.

However, American culture is attaching personal interests and substance-oriented, and despise collective interest and moral-oriented. It is more tolerance and freedom for the people, and the sermon and a lack of discipline to themselves. Such violent incidents of American university campus shooting, social problems such as drug addicts, homosexuals are rampant. Those are greater risk of affecting social stability and development.

\section{ENLIGHTENMENT OF MANAGEMENT IN AMERICAN MULTI-CAMPUS UNIVERSITY}

Throughout the situation comparison of multi-campus university management between America and China, we can see, both pattern and the system are not the same, only on the same form that have number of campuses. At present, the campus of China's university does not have the basis of the theory and practice to be the US-style campus. It is also not consistent with Chinese national conditions. But we can still be inspired by some successful experience from the United States.

1) Take Different Management Model Depending on Its Situation: Multi-campus universities in China are formed with vary causes, the administration should allow the individual university to explore its management mode according to its own situation and characteristics of practice.

2) Form the Complete System of Educational Quality: University determines clear idea of running in quality system. The government departments should develop a set of policy guidelines, while the universities play the initiative and develop special measures and mechanisms according to the actual situation, and then those works could arouse the enthusiasm of teachers and students and contribute to improving the quality of education.

3) Innovating New Model of Running School: Some multi-campus university with serious problem for funds should be assets reorganization. Introducing capital and changing the public nature, introducing the external power, to form multi-mode school. Then it could reduce the burden of countries.

4) Taking the Road with Characteristics: Autonomy of the multi-campus university experience in U.S. for reference, we should uphold the principle of combination of nationalization and internationalization in China, creating a multi-campus university autonomy model with Chinese characteristics.

\section{CONCLUSION}

Since management performance is an important issue in the multi-campus universities, the comparison on the concept of multi-campus universities between the US and China is draw to the difference. And background of formation of their multi-campus universities are compared and analyzed. Then the teaching quality system management features, financing channels, communication of teachers and students, cultural combination characteristics of the multi-campus universities in the US are illustrated. Finally, the successful experiences of the multi-campus universities from the United States are pointed out.

\section{ACKNOWLEDGMENT}

The authors would like to acknowledge the financial support of the 2010 China Humanities and Social Research Special Task Project Foundation of the Ministry of Education (Grant No. 10JDSZ3034); Higher Education Project in Fundamental Research Foundation of China Central Universities (Grant No. 2011SJ006); Research on the Construction of Campus Culture Project Foundation, South China University of China (Grant No. x2hjD2120970).

\section{REFERENCES}

[1] C. Kerr and M.L. Gade, "The Guardians: Boards of Trustees of American Colleges and Universities," Association of Gov-earning Boards of University and Colleges, Washington, D.C, 1989.

[2] B.Gumprecht, "The Campus as a Public Space in the American College Town,” Journal of Historical Geography, vol.33(1), Jan. 2007, pp. 72-103.

[3] M.Ardis, E. Hole and J. Manfredonia, "Creating a Marketplace for Multidisciplinary Multi-university System Engineering Capstone Projects," Procedia Computer Science, vol.16, Jan. 2013, pp. 10361042.

[4] H.L. Lan and H.X. Cen, "Comparative Study of Multi-campus University Management among China and Foreign Countries,” Higher Education Exploration, vol.4, Apr. 2005, pp. 37-39.

[5] Y.H. Wu and Z.G. Zhang, "Research on Effectiveness of Ideological and Political Education of College Students Based on Voluntary Service Activities - A Case Study of Volunteer in Guangzhou Asian Games,” Studies in Ideological Education, vol.9, Sep. 2011, pp. 668672.

[6] Q.Y. Huang, “Quality Education in the United States,” Guangdong Education Press, Apr. 2000. 